\title{
Short Communication: Pollen diversity in the Bogor Botanic Gardens, Indonesia
}

\author{
SUDARMONO \\ Research Centre for Plant Conservation and Botanic Gardens (Bogor Botanic Gardens), Indonesian Institute of Sciences. Jl. Ir. H. Juanda No. 13, Bogor \\ 16122, West Java, Indonesia. Tel./fax.: +62-251-8322-187, `email: s_darmono@yahoo.com
}

Manuscript received: 12 September 2016. Revision accepted: 2 March 2019.

\begin{abstract}
Sudarmono. 2018. Short Communication: Pollen diversity in the Bogor Botanic Gardens, Indonesia. Biodiversitas 20: 931 936. Pollen morphology influenced the process of plants evolution. Bogor Botanic Gardens has many living collections in terms of pollen diversity. The purpose of this study was observed at the diversity of pollen morphology at the Bogor Botanic Gardens and its implications for the pollen conservation of plants in the collection. The method used is cleaning the pollen using Glacial Acetic Acid (AAG), then examined using a light microscope in the tissue culture laboratory of Bogor Botanic Gardens. There were 35 specimens that were analyzed and the results were randomly shaped pollen from radial symmetry or bilateral symmetry to its combination with monocolpate, tricolpate, pericolpate and stephanocolpate. While aperture types were the monoporate type with 5 specimens, monocolpate 10 specimens, tricolpate 11 specimens, stephanocolpate 4 specimens, periporate 4 specimens, and syncolpate 1 specimen. Three specimens families Caesalpiniaceae (order Fabales) has the shape of pollen vary, i.e radial symmetry monocolpate and radial symmetry tricolpate. Similarly, two specimens of the family Araliaceae (Apiales) different shapes, namely radial symmetry and bilateral symmetry tricolpate. In Asteraceae and Asclepiadaceae has the same shape, the radial symmetry tricolpate. Overall of 35 specimens then there are 22 specimens of radial symmetry and 13 specimens of bilateral symmetry. For the same family have the same ornamentation, for example in the Lamiaceae, Malvaceae, and Rutaceae. But the uniqueness occurs in the family of Arecaceae or palm family that show the diversity in the shape and size of pollen in each genus. Pollen morphology analysis through a combination of morphological data, palynology, and molecular samples more would be better. Pollen bank as pollen in the living collections of Bogor Botanic Gardens is needed to germplasm conservation of endangered plants in Indonesia.
\end{abstract}

Keywords: Bogor Botanic Gardens, conservation, palynology, pollen

\section{INTRODUCTION}

The process of evolution of plants associated with pollen, which carry pollen approached the male and female gametophyte in ovum. Male gametophyte or sperm of seed plants fertilize the female gametophyte is moving within a vessel so as to facilitate the movement and shapeing seeds. In an evolutionary perspective, the seed is the development of a very important feature. Megaspore in ovulum protected by a layer of tissue called the sporophyte integument. In the ovulum also a food source that will be used for the development of the embryo. Once conception has occurred, the integument hardens into a nutshell. The seed coat protects the embryo from a difficult external environment, such as temperature, drought, pressure, and others, which makes seeds can be dormant for a considerable period of time. Evolution of pollen in plants caused success on the diversity of plants on earth (Septina 2004).

The pollen has long been used for the identification of fossil pollen through which the outer layer (shell) hard. The body shell is resistant to acid, alkali intense heat even though parts of it are only able to live in a few days or weeks. Therefore pollen in each species, both living and fossilized described as human fingerprints (Bryant et al. 1990). Bogor Botanic Gardens, West Java, Indonesia is an ex situ conservation Institute which is under the Indonesian
Institute of Sciences (LIPI) has collected live plants from various regions in Indonesia even some rare plants from around the world. Based on the Bogor Botanic Gardens living collection catalog that in 2009 there were 14,585 specimens consisting of 3,411 species; 1,259 genera and 215 families, of this amount, does not include orchids, pitcher plants, Hoya and collections in the greenhouse (Sari et al., 2010). Collection of existing plants are still 2,465 unidentified species, 7 genera and 221 families were not yet known scientific name altogether. For that is expected from 35 specimens of plant collections were identified pollen can find some relationship families. Identification of pollen is very important for plants that are flowering so that the flower morphology and pollen can be known classification is least at the level of families (Abu-Asab and Cantino 1992, 1994). Besides inshapeation about the pollen is still very limited, that aspect of pollen fossils used by geologists alone, whereas Palynology aspects still little inshapeation.

Deposit the pollen in genebanks also ensure the availability throughout the year for basic biology and allergy research program (Shivanna 2003). Pollen as the male sex organ in plants has diversity in size and inshapeation relating to the long-term viability of the pollen of many diverse species. Pollen also serves as a source of genetic diversity. This study aims to provide inshapeation about the shape of pollen morphology, shape, size and its 
implications for the conservation of plants in the collection of the Bogor Botanic Gardens.

\section{MATERIALS AND METHODS}

Pollen samples from several plant collections in the Bogor Botanic Gardens, Bogor City, West Java, Indonesia randomly selected on 35 specimens (Table 1). Pollen taken from their flowers by using tweezers or a scalpel Jaru. The method used in the manufacture of these preparations is Acetolysis which is acetolysed by using acid. Acetolysis process always uses acid. Dialysis part is dirt on the walls of pollen to be clean so easily observed. Cleaning occurs at the time of soaking pollen in Glacial Acetic Acid (AAG). Function of centrifuge with Acetic Acid and Sulphuric is to precipitate pollen, making it easy to separate it from the dirt on the turnover time of liquids. This process can be repeated several times until the pollen can be completely clean of dirt. After that stained with safranin and covered with a glass lid that previously spilled pollen with glycerin solution as adhesives and every corner of the glass cover by a little tiny piece of paraffin. The glass is done carefully to minimize the possibility arises of a bubble, then mounted on a microscope slide and examined using a light microscope in the laboratory of Bogor Botanic Gardens, Indonesian Institute of Sciences (LIPI). The light microscope (LM) is used, namely Olympus BX53M series has a resolution of about $200 \mathrm{~nm}$, which is good enough to see the pollen. The size of pollen divided into six classes, based on the longest axis (except on pollen echinate, the thorns are not included in the size). The size of the class divisions are: $<10 \mu \mathrm{m}=$ very small; $10-25 \mu \mathrm{m}=$ small; 25 $50 \mu \mathrm{m}=$ moderate; $50-100 \mu \mathrm{m}=$ large $; 100-200 \mu \mathrm{m}=$ very large; $>200 \mu \mathrm{m}=$ giant (Susandarini 2010). After the pollen is identified, they can be plotted on a diagram of pollen, which is then used for the interpretation of the shape based Erdtman (1952) and Kapp (1969). Shape of pollen in the size of its (radial symmetry and bilateral symmetry) (Erdtman 1952), combined type aperture according to Kapp (1969) are classified as follows: monoporate, diporate, triporate, stephanoporate, periporate, monocolpate, dicolpate, tricolpate, stephanocolpate, pericolpate, heterocolpate, syncolpate, tricolporate, stephanocolporate, pericolporate and trichotomocolporate (Figure 1).

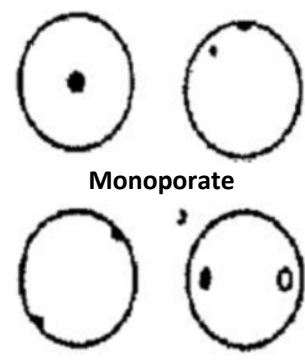

Diporate

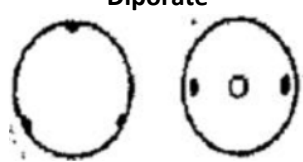

Triporate

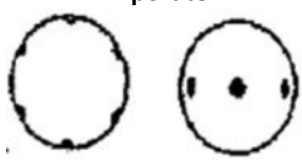

Stephanoporate

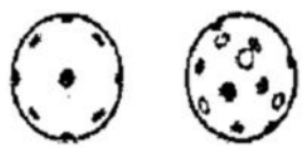

Periporate

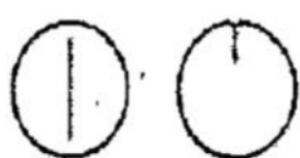

Monocolpate

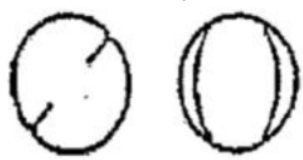

Dicolpate

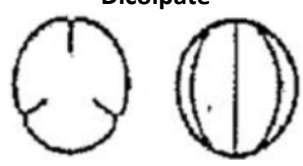

Tricolpate

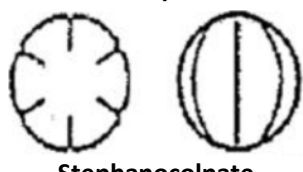

Stephanocolpate
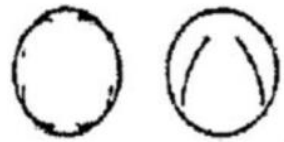

Pericolpate
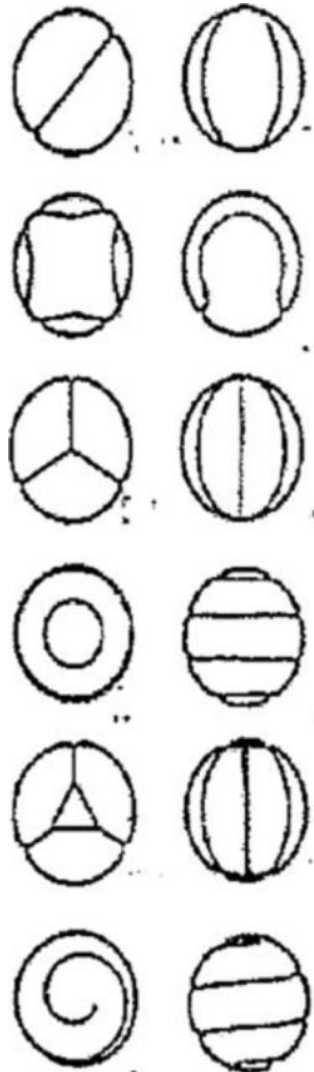

Syncolpate
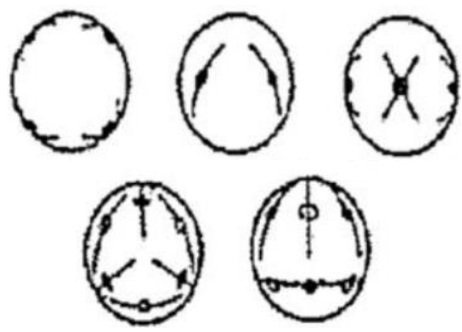

Pericolporate

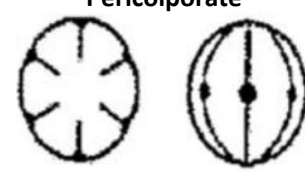

Stephanocolporate

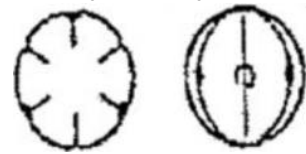

Heterocolpate

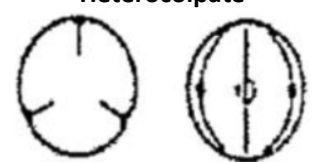

Tricolporate
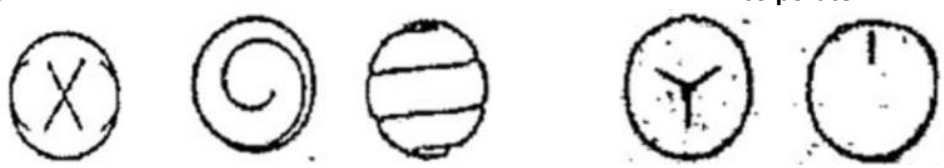

Trichotomocolporate

Figure 1. Aperture types of pollen-based on Kapp (1969) 


\section{RESULTS AND DISCUSSION}

The results of the study in Table 1 and Figure 2, shows that the eight specimens family Arecaceae (Palm, order Arecales) have different shapes, as well as the members of the family Verbenaceae (Lamiales), Araliaceae (Apiales), and Caesalpiniaceae (Fabales) whose specimen more than one. This is in accordance with the opinion of Ferguson and Harley (1993), that for a family of monocots, the families Arecaceae have variations pollen, not only in the number of aperture and orientation but also in exine ornaments. While on pollen family Lamiaceae (order Lamiales), Malvaceae (Malvales) and Rutaceae (Sapindales) have the same shape. In the family Lamiaceae, namely radial symmetry stephanocolpate with varying sizes from small, moderate and large at 4 specimens. Abu-Assab and Cantino (1992) state that the morphology of the pollen to the family Lamiaceae pollen classification could prove decisive at the family level. It is also supported by a study of pollen morphology Lamiaceae family members on Phlomis L., Marrubium L. and Stachys L. (Abu-Assab and Cantino 1994). Nevertheless for the application of the classification between species is still very limited, it is as expressed by Moon and Hong (2003) for the genus Lycopus (Lamiaceae). Family Lamiaceae, Verbenaceae and Bignoniaceae is a member of the same order, there is order Lamiales, but differ in terms of their morphology (Figure 2; no. 9-11 family Verbenaceae, no. 12 families Bignoniaceae, no. 13-16 families Lamiaceae). Three specimens to the family Verbenaceae are two specimens of the same shape, i.e bilateral symmetry tricolpate and one specimen radial symmetry tricolpate.

Pollen in the family Malvaceae (order Malvales) radial symmetry periporate, large sized $(50-100 \mu \mathrm{m})$ all on four specimens, but with a characteristic prickly on exine surface (Figure 2; no. 17-20). According to Aprianty and Kriwiyanti (2008), generally, class sizes based on the index $\mathrm{P} / \mathrm{E}$ of pollen of Hibiscus (Hibiscus rosa-sinensis L.; family Malvaceae) with 10 different colors crown-shaped prolate spheroidal, type apertures and ornamentation exine is polypantoporate periporate. While in the same order (Malvales), Pachira affinis (Martelli) Bakh. as members of the family Malvaceae which pollen shape is different i.e bilateral symmetry tricolpate (Figure 2; no. 21). Two specimens family Rutaceae (order Sapindales, Figure 2; no. 22 and 23) have the similar shape, the radial symmetry monoporate and small size, but differ in the same order for members of the family Sapindaceae (Allophylus cobbe (L.) Raeusch.) on Figure 2; no. 24. In the Rutaceae family members, subtribe Cuspariinae pollen from 111 collections of 71 species and 24 genera were examined by LM, SEM and TEM showed pollen morphology is very diverse (Morton and Kallunki 1993). Three specimens families Caesalpiniaceae (order Fabales) has the shape of pollen vary, i.e radial symmetry monocolpate and radial symmetry tricolpate (Figure 2; no. 30-32). Similarly, two specimens of the family Araliaceae (Apiales) different shapes, namely radial symmetry and bilateral symmetry tricolpate (Figure 2; no. 26 and 27). In Asteraceae (Figure 2; no. 33) and Asclepiadaceae (Figure 2; no. 35) has the same shape, the radial symmetry tricolpate. Overall of 35 specimens then there are 22 specimens of radial symmetry and 13 specimens of bilateral symmetry. While there is 5 specimens monoporate shape, 10 specimens monocolpate, 11 specimens tricolpate, 4 specimens stephanocolpate, 4 specimens periporate, and 1 specimen syncolpate.

For size of pollen existing are 17 specimens for small size and 9 specimens for moderate and large size. Variations in pollen are very high both in shape and size so that the classification of the family requires a specimen of each family in high quantities. However, three-dimensional view aspect is difficult to see in detail if used only light microscope, so that the need for using scanning electron microscopes (SEM) to see more detail and magnification can 1000 times. According to Sarwar et al. (2015), that the pollen characters themselves do not seem to correlate clearly with Bomarea subgenus classification (family Alstroemeriaceae). In this case, the subgenus classification levels or genus may differ in terms of pollen morphology, especially for plant taxonomic classification levels above genus such as order and clade.

The uniqueness occurs in the specimen of Arecaceae or palm family members with 9 specimens show a radial symmetry monoporate on one specimen, bilateral symmetry monoporate on one specimen, bilateral symmetry monocolpate 3 specimens, and there are four radial symmetry monocolpate specimens with small and moderate size. As revealed by Harley and Baker (2001), that the majority of species in the family Arecaceae have pollen monocolpate, 17 types aperture, and 13 types exine. Rasheed et al (2016) also found that the pollen morphology of 8 species (subfamily Arecoideae) clearly shows that four pollen types have been recognized such as Areca-type, Dypsis-type, Cocos-type and Elaies-type. Harley \& Dransfield (2003) described that rare triporate pollen phenomena in palms wich is two rare examples of triporate pollen, one in Areca and the other in Sclerosperma, as well as the co-occurrence of zonosulcy in Areca. Kumar \& Ramaswamy (2003) justified that the pollen morphology of Calamus is distinct from all other palm species in having dicolpate pollen grains. Thus, the character aperture or the surface of the pollen that is thin and soft showed no relation between the evolution of the family Arecaceae or palm with relationship diagram or phylogeny of the family. Erdtman (1986) mentioned that the shape, size or type of pollen can also vary according to the stage of ripeness.

Pollen research from some experts on several plants in Europe by Faegri and Iversen (1989) show the variation of size based on geography. But efforts to link the shape and size of pollen which varies in determining their evolutionary process has not given satisfactory results. Pollen size of different individuals in one type can also be caused by differences in optical focusing observers. Morphological characterization needs to be supported by characterization using molecular markers. Molecular markers can give an idea of relationship is more accurate, since the analysis deoxyribo nucleic acid (DNA) as the genetic material is not influenced by environmental conditions (Dwiatmini et al. 2003). Bomarea subgenus classification (family Alstroemeriaceae) can only be done 
on the morphology of the pollen when analyzed through a combination of morphological data, Palynology, and molecular samples more on specimens of all species of genus Bomarea (Sarwar et al. 2015). Even so, pollen can be used to identify the plants because of the pollen there exine which has a structure and ornamentation typical and preserved because it contains sporopollenin resistant organic material and acetolysis (Faegri and Iversen 1989).

Bogor Botanic Gardens seeks to capitalize on the results of his plant collection in conservation efforts in an attempt to prevent its extinction in the forests of Indonesia. Conservation is a maintenance effort and the protection/ preservation of germplasm regularly to prevent/avoid damage and extinction. The conservation is not only to protect and preserve, but must be used sustainably. Bogor Botanic Gardens basically approach for the conservation of germplasm that ex-situ. Ex situ conservation is the protection, conservation, and utilization of germplasm outside their natural habitat. This conservation can be done in the field (garden collection) as well as in the room/laboratory (pollen storage, cryopreservation/storage freezing temperatures). Implementation on the conservation of pollen, which is done to address the storage of flowering is not the same. Storage of these materials is also considering the seed moisture content, temperature and relative humidity of storage space.

Table 1. Specimens name, family, order, the site at Bogor Botanic Gardens (BBG) and shape as well as size category of pollen

\begin{tabular}{|c|c|c|c|}
\hline No. Latin name, author, family and order & Location at BBG & Shape & Size \\
\hline 1. Licuala spinosa Wurmb. Arecaceae. Arecales & Vak II; V; XIII & Bilateral symmetry monoporate & Small \\
\hline $\begin{array}{l}\text { 2. Acoelorrhaphe wrightii (Griseb. \& H.A. Wendl. Ex Becc. } \\
\text { Arecaceae. Arecales }\end{array}$ & Vak V & Bilateral symmetry monocolpate & Small \\
\hline $\begin{array}{l}\text { 3. Ptychospema macarthuriil. (H. Wendl. Ax H.J. Veitch) H. } \\
\text { Wendl. Ex Hook. F. Arecaceae. Arecales }\end{array}$ & Vak II; X; XII; XIV & Bilateral symmetry monocolpate & Small \\
\hline $\begin{array}{l}\text { 4. Syagrus schizophylla (Mart) Glassman Coco Calole } \\
\text { Arecaceae. Arecales }\end{array}$ & Vak V; XVI & Bilateral symmetry monocolpate & Small \\
\hline 5. Caryota mitis Lour. Arecaceae. Arecales & Vak II; V; X; XII; XIV & Radial symmetry monocolpate & Small \\
\hline $\begin{array}{l}\text { 6. Pinanga coronata (Blume ex Martelli) Blume Arecaceae. } \\
\text { Arecales }\end{array}$ & Vak V; X; XI; XII; XIII & Radial symmetry monocolpate & Moderate \\
\hline 7. Lodoicea maldivica (Gmel.) Pers. Arecaceae. Arecales & Vak XIX & Radial symmetry monocolpate & Moderate \\
\hline 8. Gronophyllum microcarpum Scheff. Arecaceae. Arecales & Vak V; XII; XIII & Radial symmetry monocolpate & moderate \\
\hline 9. Geunsia pentandra (Roxb.) Merr. Verbenaceae. Lamiales & Vak XI & Bilateral symmetry tricolpate & Small \\
\hline 10. Callicarpa pedunculata R.Br. Verbenaceae. Lamiales & Vak XI; XV & Bilateral symmetry tricolpate & Small \\
\hline 11. Clerodendrum confusum Hall. f. Verbenaceae. Lamiales & Vak XI & Radial symmetry tricolpate & Large \\
\hline 12. Kigelia africana Lam. (Benth.) Bignoniaceae. Lamiales & Vak XI; XV & Radial symmetry tricolpate & Moderate \\
\hline $\begin{array}{l}\text { 13. Ortosiphon aristatus (putih) (Blume) Miq. Lamiaceae. } \\
\text { Lamiales }\end{array}$ & Vak XXIV & Radial symmetry stephanocolpate & Large \\
\hline 14. Ortosiphon aristatus (ungu) (Blume) Miq. Lamiaceae. & Vak XXIV & Radial symmetry stephanocolpate & Large \\
\hline
\end{tabular}
Lamiales

15. Plectranthus scutellarioides (L.) R.Br. Lamiaceae. Lamiales Vak XXIV

16. Ocimum canum Sims. Lamiaceae. Lamiales Vak XXIV

17. Malvaviscus arboreus Cav. var. mexicanus Schlecht. Vak II Malvaceae' Malvales

18. Malvaviscus arboreus Cav. var. longifolius Malvaceae. Vak XV; XVI Malvales

19. Hibiscus rosa-sinensis L. Malvaceae. Malvales

20. Hibiscus huegelii Endl. Malvaceae. Malvales

Vak XV; XXIV

Vak XV

21. Pachira affinis (Martelli) Bakh. Malvaceae. Malvales Vak XVI

22. Melicope latifolia (DC) T.G. Hartley. Rutaceae. Sapindales Vak XI; XXIV

23. Euodia hortensis J.R. \& G. Forst Rutaceae. Sapindales Vak XXIV

24. Allophylus cobbe (L.) Raeusch. Sapindaceae. Sapindales Vak III; XI; XV; XVII

25. Amorphophalus titanium (Becc.) Becc. Aracaceae.

Vak VI; I Alismatales

26. Trevesia burckii Boerl. Araliaceae. Apiales Vak XI; XIII

27. Schefflera farinosa (Blume) Merr. Araliaceae. Apiales Vak XIII; XV

28. Carmona retusa (Vahl.) Masam. Boraginaceae. Boraginales Vak XXI; XXIV

29. Saurauia $s p$. Actinidiaceae. Ericales Vak XI; XIX

30. Saraca thaipingensis Cantley ex Prain Caesalpiniaceae. Vak I; XI; XII Fabales

31. Cynometra cauliflora L. Caesalpiniaceae. Fabales

32. Brownea capitella Jacq. Caesalpiniaceae. Fabales

33. Stifftia chrysantha Mikan Asteraceae. Asterales.

Vak I; X; XI

Vak I; XII

Vak III; XVI

34. Eusideroxylon zwageri Teijsm. \& Binn. Lauraceae. Laurales Vak V; VIII; IX; XVI

35. Tabernaemontana hystrix Steud. Asclepiadaceae.

Vak XVI

Radial symmetry stephanocolpate Small

Radial symmetry stephanocolpate Moderate

Radial symmetry periporate Large

Radial symmetry periporate Large

Radial symmetry periporate

Radial symmetry periporate

Bilateral symmetry tricolpate

Radial symmetry monoporate

Radial symmetry monoporate

Bilateral symmetry tricolpate

Radial symmetry monoporate

Large

Large

Moderate

Small

Small

Small

Radial symmetry tricolpate Small

Bilateral symmetry tricolpate Small

Bilateral symmetry syncolpate Small

Bilateral symmetry monocolpate Moderate

Radial symmetry monocolpate Moderate

Radial symmetry tricolpate Small

Radial symmetry monocolpate Moderate

Radial symmetry tricolpate Large

Radial symmetry monoporate Small

Radial symmetry tricolpate Small Gentianales 


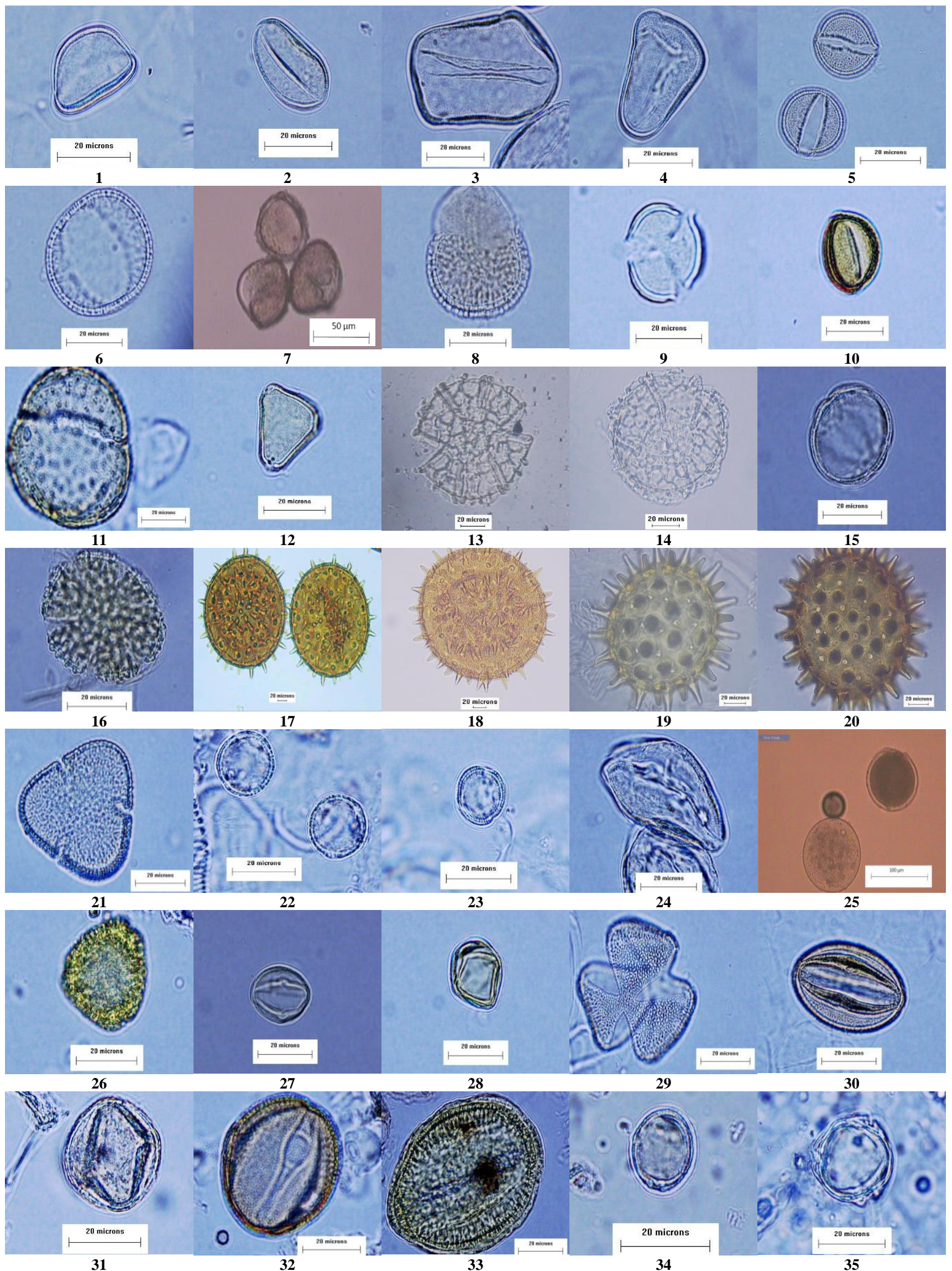

Figure 2. Pollen morphology of 35 specimens plant collections at Bogor Botanic Gardens. Specimen names following by Table 1. Size scale following each number 


\section{ACKNOWLEDGEMENTS}

Acknowledgements aimed at the Supervisor in the location subdiscipline in the Bogor Botanic Gardens who can not mention one by one. As well as on the research license by the Head of Section Collection and Seedling BBG, Dr. Izu Andry Fijridiyanto. Also, our thanks go to Dr. Graham Eagleton, from Australian Volunteers for International Development, for English language editing of the manuscript, Dr. Widodo and Dr. Heru Kiswantoro for reviewing this paper. This research was partially funded by In-house Research DIPA Bogor Botanic Gardens, LIPI.

\section{REFERENCES}

Abu-Assab MS, Cantino PD. 1992. Pollen morphology in subfamily Lamioideae (Lamiaceae) and its phylogenetic implications. In: Harley RM and Reynolds T (eds.). Advances in Science Lamiaceae. Royal Botanic Gardens, Kew.

Abu-Assab MS, Cantino PD. 1994. Systematic implications of pollen morphology in subfamilies Lamioideae and Pogostemonoideae (Labiatae). Ann Missouri Bot Gard 81: 653-686.

Aprianty NMD, Kriwiyanti E. 2008. Studies of pollen size variations Hibiscus (Hibiscus rosa-sinensis L.) with different flower colors. J Biol 12 (1): 14-18.

Bryant VM., Mildenhall DC, Jones JG. 1990. Forensic Palynology in the United States of America. Palynology 14: 193-208.

Dwiatmini K, Mattjik NA, Aswidinoor H, Matthew NIT. 2003. Analysis of clustering and phylogenetic relationship based Phalaenopsis orchids species determination key phenotypically plastic and RAPD molecular markers. J Hort 13 (1): 16-27.

Erdtman G 1952. Pollen morphology and plant taxonomy, Angiosperms. The Chronica Botanica Co., Walthan, MA.
Erdtman G 1986. Pollen and Plant Taxonomy Angiosperms. Hafner Publ. Co., New York.

Faegri K, Iversen J 1989. Textbook of Pollen Analysis. John Wiley \& Sons, New York.

Ferguson IK, Harley, MM 1993 The significance of new and recent work on pollen morphology in the Palmae. Kew Bull 48: 205-243.

Harley MM, Baker WJ 2001 Pollen aperture morphology in Arecaceae: Application within phylogenetic analyses, and a summary of record of palm-like pollen the fossil. Grana 40: 45-77.

Harley MM, Dransfield J 2003. Triporate pollen in the Arecaceae. Grana 42: 3-19.

Kapp RO. 1969. How to know pollen and spores. W. C. Brown Co. Publ. Dubuque, Iowa.

Kumar HNK, Ramaswamy SN. 2003. Contributions to the Study of Microsporogenesis in Calamus L. (Arecaceae). Taiwania 48 (3): 180193.

Moon HK, Hong SP. 2003: Pollen morphology of the genus Lycopus (Lamiaceae). Ann Bot Fennici 40: 191-198.

Morton CM, Kallunki JA. 1993. Pollen morphology of the Subtribe Cuspariinae (Rutaceae). Brittonia 45 (4): 286-314.

Rasheed AA, Perveen A, Abid R, Qaiser 2016. Pollen morphology of the subfamily Arecoidea Griff. (Family-Arecaceae) from Pakistan and Kashmir. Pakistan J Bot 48 (3): 1051-1060.

Sari R, Ruspandi, Ariati SR. 2010. An Alphabetical List of Species Cultivated in the Bogor Botanic Gardens. Republic of Indonesia. Indonesian Institute of Sciences. Center for Plant Conservation, Bogor Botanic Gardens, Bogor

Sarwar AKM, Golam, Hoshino Y, Araki H. 2015. Pollen morphology and its taxonomic significance in the Genus Bomarea Mirb. - I. Subgenera Baccata, Sphaerine, and Wichuraea. Acta Botanica Brasilia 29 (3): 425-432.

Septina S. 2004. Relationship between Multiple Mulberry Plants (Morus sp.) based on Pollen Morphology. Diponegoro University, Semarang, [Indonesian]

Susandarini R. 2010. Pollen Preparation Techniques and Observation of Pollen Preparations. Universitas Gadjah Mada, Yogyakarta. [Indonesian] 